\title{
BRUCELLA ABORTUS AGGLUTININS IN THE SERA OF PREGNANT WOMEN AND BLOOD DONORS
}

\author{
BY \\ H. G. BARTRAM \\ County Public Health Inspector, Oxfordshire \\ P. W. BOTHWELL \\ Bristol Health Department and Department of Public Health, University of Bristol \\ W. H. H. JEBB \\ Public Health Laboratory, Oxford \\ A. MCDIARMID \\ Agricultural Research Council Field Station \\ AND \\ A. E. PRESTON \\ National Blood Transfusion Service, Oxford Regional Hospital Board
}

The incidence of brucellosis in the human population of England and Wales is still not accurately known, although estimates have been made (Wilson, 1932; Dalrymple-Champneys, 1950). Few persons who acquire $B r$. abortus develop any obvious clinical disease, but the existence of $B r$. abortus agglutinins in blood sera indicates past exposure to the organism.

A survey of human and animal brucellosis made between 1957 and 1959 in the Oxford area (Bothwell, 1960 a, b, c, 1961; McDiarmid, 1960a, b, 1961) included the examination of 3,431 sera samples from pregnant women and of 8,690 samples of sera from blood donors for thepresence of Br.abortusagglutinins. Both types of sera are readily available; both have limitations for survey purposes. Blood donor serum cannot be regarded as a normal sample compared with a cross-section of the general population, since blood donors are in fact highly-selected healthy persons. The serum from pregnant women also constitutes a selected sample. The incidence of agglutinins in both samples may represent an underestimate of the incidence of agglutinins in the general population.

The results of both surveys are given, with notes on the investigation of milk supplies consumed by pregnant women with agglutinins to Br. abortus.

\section{MethodS}

3,431 samples of blood sera from pregnant women, submitted between 1957 and 1959 for Rhesus and Kahn testing, were examined for Br. abortus agglutinins at the Oxford Public Health Laboratory, using the standard Public Health Laboratory Service (PHLS) antigen and reading dilutions of $1 / 25$ to $1 / 250$. The samples were drawn from the population of the northern two-thirds of Oxfordshire, but not from the city of Oxford. The 3,431 samples represented about 90 per cent. of all pregnancies in the area sampled.

The 8,690 samples provided by the Oxford blood transfusion unit were drawn from a wide area in the Oxford region between 1958 and 1959; they were examined at the Agricultural Research Council's Field Station at Compton, using final dilutions of $1 / 10,1 / 20,1 / 40,1 / 60$, etc. WHO/FAO antigen was used and, taking 50 per cent. agglutinations as the end-point, positive reactions were recorded at dilutions of $1 / 10$ and above. Tests for blocking antibodies were not made.

\section{RESULTS}

\section{Sera from Pregnant Women}

This serum survey made use of routinely-collected ante-natal serum samples; thus only pregnancies lasting more than 3 months are included. To ascertain fully the risk of abortion in the human subject, as reported by Huddleson (1943), Williamson (1944) and Dalrymple-Champneys (1960), it would be desirable to survey a group of women at risk of pregnancy and to follow their conception and early pregnancy history. Most of the pregnant women whose sera gave a positive result were in the age group 20 to 25 (range 17 to 35 ). The stage of pregnancy at which serum was tested was usually between 3 and 5 months. 
Of the 3,431 sera examined, 35 (1.02 per cent.) were positive at a level of $1 / 25$ or greater, as shown in Table $I$, which also shows the distribution of occupations at the various titres.

\section{TABLE I}

RANGE OF BR. ABORTUS AGGLUTININ TITRES IN 3,431 SERUM SAMPLES FROM PREGNANT WOMEN (PHLS ANTIGEN) AND OCCUPATIONAL DISTRIBUTION

\begin{tabular}{|c|c|c|c|}
\hline \multirow{2}{*}{ Titre } & \multirow{2}{*}{$\begin{array}{c}\text { No. of } \\
\text { Samples }\end{array}$} & \multicolumn{2}{|l|}{ Occupation } \\
\hline & & $\begin{array}{l}\text { Agricultural, Dairying and } \\
\text { Veterinary work }\end{array}$ & $\begin{array}{l}\text { Other or } \\
\text { Unknown }\end{array}$ \\
\hline $\begin{array}{l}1 / 25 \\
1 / 50 \\
1 / 100 \\
1 / 125 \\
1 / 250 \\
1 / 1000 \\
1 / 2500 \\
1 / 5000\end{array}$ & $\begin{array}{r}12 \\
15 \\
2 \\
2 \\
1 \\
1 \\
1 \\
1\end{array}$ & $\begin{array}{l}2 \\
5 \\
1 \text { (farm domestic) } \\
1 \text { (veterinary worker) } \\
= \\
1 \text { (farmer) } \\
1 \text { (farmer's wife) }\end{array}$ & $\begin{array}{r}10 \\
10 \\
1 \\
1 \\
1 \\
1 \\
-\end{array}$ \\
\hline
\end{tabular}

Proportion of positive sera 35 out of 3,431 (1.02 per cent.). Proportion of $1 / 100$ or over 8 out of $3,431(0 \cdot 23$ per cent.).

Of the 35 positive cases, eleven ( $31 \cdot 5$ per cent.) had some connexion with occupations concerned with cattle, twenty $(57 \cdot 1$ per cent.) had no such connexion, and in four (11.4 per cent.) the occupational background was unknown. The highest titres $(1 / 2500$ and $1 / 5000)$ were found in a farmer's wife and a woman farmer.

Among cases of clinical brucellosis recorded in England and Wales, $22 \cdot 8$ per cent. have an occupational connexion with farming (PHLS figures for 1957: Wilson, 1961).

Nearly all the positive sera in this series came from women who lived in rural areas and would have had opportunities to consume raw milk in the recent past, and the eleven women living on farms or otherwise connected with cattle also had opportunities for contact with infected animals.

Definite histories of recent consumption of raw milk were obtained from fifteen of the 35 women with Br. abortus agglutinins (twelve drank T.T. milk, and three ungraded milk).

24 (68.6 per cent.) could be classified as rural residents, eight ( 22.9 per cent.) as living in a small town, and two (5.7 per cent.) as city dwellers; in the remaining case the place of residence was unknown.

Questions about symptoms suggestive of brucellosis in the history of these $\mathbf{3 5}$ women revealed only one with a history of "glandular fever". The pregnancies were all uneventful and normal babies resulted, although eight had a titre at or in excess of $1 / 100$. In addition, Dr. J. M. Payne of Compton examined the placentae from twelve of the women, and found no evidence of brucella organisms or lesions suggestive of brucellosis.

In five of these positive cases ( $14 \cdot 3$ per cent.), a follow-up resulted in the discovery of an infected herd of cows (Table II). This compares with an infection rate of about 5 per cent. in herds in generab in this area on one sampling (McDiarmid, 1960b) Four of these five cases, however, came from an area where herd infection is in any case quite high; and three of these lived on a farm. Eight clinical cases of human brucellosis had occurred in this particular area in the previous 8 years.

TABLE II

DETAILS OF BRUCELLA-INFECTED HERDS FOUND BY MILK SUPPLY INVESTIGATIONS IN FIVE PREGNANT WOMEN WITH BLOOD SERUM AGGLUTININS TO BR. ABORTUS

\begin{tabular}{|c|c|c|c|c|c|c|}
\hline \multirow{2}{*}{$\begin{array}{l}\text { Case } \\
\text { No. }\end{array}$} & \multirow{2}{*}{ Residence } & \multicolumn{2}{|c|}{ Occupation } & \multicolumn{2}{|c|}{ Titre } & \multirow{2}{*}{ Milk Supply and Other Circumstances } \\
\hline & & Self & Husband & 1st & 2nd & \\
\hline 1 & Village & Clerical & Factory Worker & $1 / 50$ & $1 / 10$ & $\begin{array}{l}\text { Present supply pasteurized, but her brother, a farm worker, } \\
\text { brought home raw milk which she drank in preference to } \\
\text { pasteurized } \\
\text { One cow at farm aborted, found positive to Brucella, re- } \\
\text { moved from herd, and slaughtered just before patient's } \\
\text { notification } \\
\text { Remainder of herd of } 57 \text { animals negative }\end{array}$ \\
\hline 2 & Village & $\begin{array}{l}\text { Domestic } \\
\text { on Farm }\end{array}$ & Bricklayer & $1 / 100$ & $1 / 50$ & $\begin{array}{l}\text { Lived } 3 \frac{1}{2} \text { years on farm and drank raw milk, but since } \\
\text { marriage, pasteurized milk } \\
\text { Brucelle isolated by culture from bulk milk at farm. Four } \\
\text { infected cows found in herd of forty. }\end{array}$ \\
\hline 3 & Farm & Housewife & Farmer & $1 / 50$ & $1 / 5000$ & $\begin{array}{l}\text { Milk supply T.T. Had no symptoms of undulant fever } \\
\text { Brucella isolated from table jug of milk } \\
\text { One cow in herd had aborted and had positive blood titre }\end{array}$ \\
\hline 4 & Farm & $\begin{array}{l}\text { Domestic } \\
\text { on Farm }\end{array}$ & Farmer & $1 / 50$ & & $\begin{array}{l}\text { Own T.T. herd. History of abortion on farm. Brother in } \\
\text { hospital with undulant fever in } 1952 \\
\text { Milk consumed by patient positive to Br. abortus. Twelve } \\
\text { cows in herd }\end{array}$ \\
\hline 5 & Village & $\begin{array}{l}\text { Domestic } \\
\text { Worker }\end{array}$ & $\begin{array}{c}\text { Estate Worker } \\
\text { Forestry }\end{array}$ & $1 / 25$ & & $\begin{array}{l}\text { Present milk supply consumed for past year T.T. Previous } \\
\text { supply pasteurized } \\
\text { Brucella isolated from farm milk by culture. Some } 10 \\
\text { gallons retailed daily. Two cows positive }\end{array}$ \\
\hline
\end{tabular}




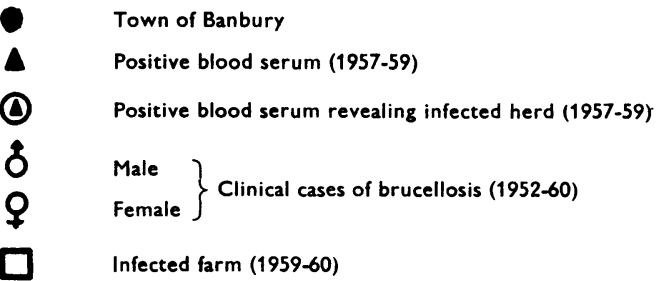

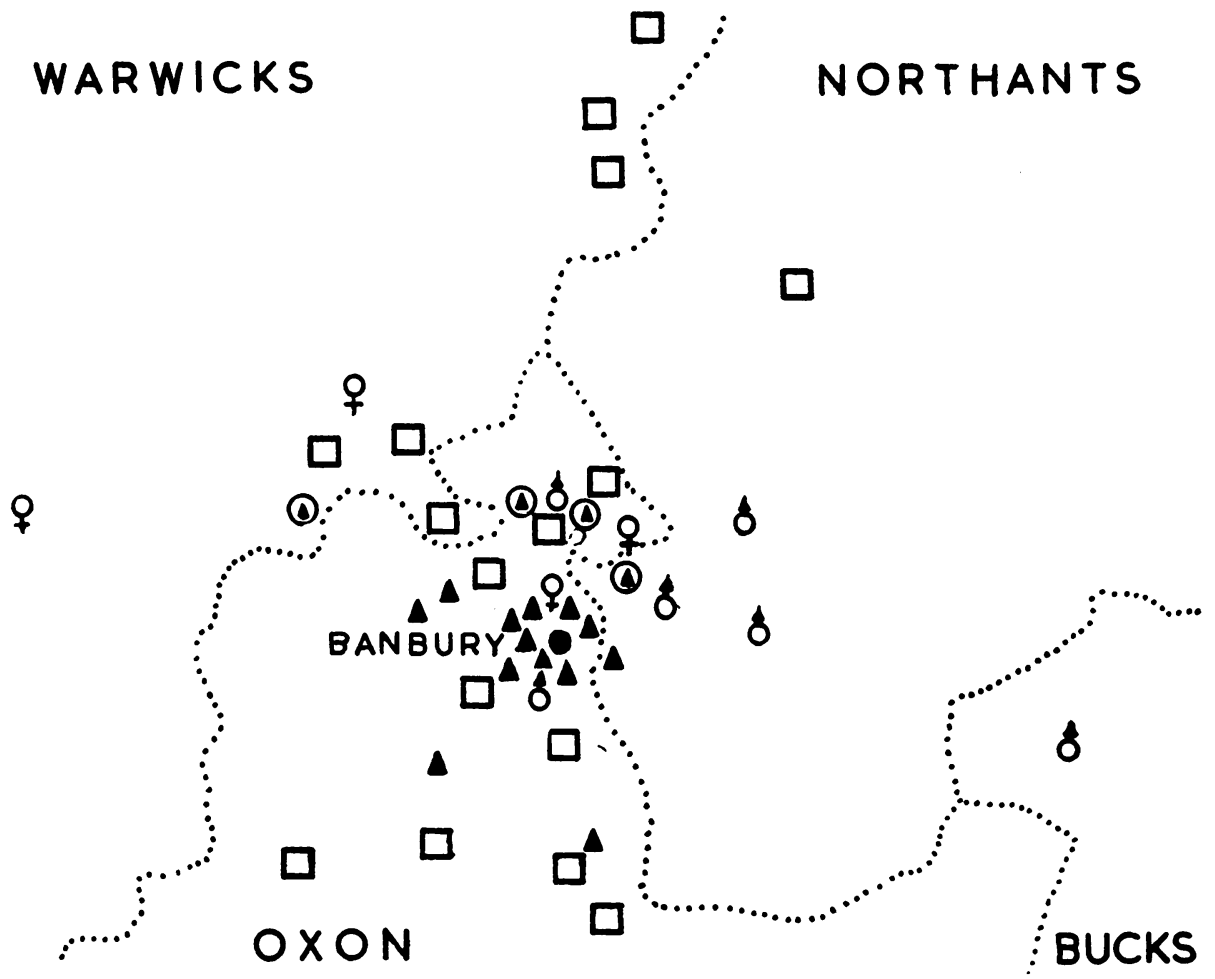

FIGURE.-Localization of infected herds, clinical cases of human brucellosis, and blood serum specimens from pregnant women showing agglutinins to Br. abortus. The starting point for action to remove brucellosis infection might be either of these three sources.

The Figure shows the localization of infected farms in the area in 1959-60, the clinical cases of human brucellosis there during the previous 8 years, and the pregnant women with agglutinins to $B r$. abortus in 1957-59. Elimination of the disease could be effected by following up clinical cases, persons with positive agglutinins, or infected herds; or all three. Examination of blood sera for Br. abortus agglutination as part of the routine testing of blood samples would be useful in cases of pregnant women who live on farms and drink raw milk, so that positive cases could be followed up.

Only 1.02 per cent. of this series of pregnant women had detectable agglutinins, while of female blood donors 0.87 per cent. were in this category (Table III); this suggests that, irrespective of the

TABLE III

BR. ABORTUS AGGLUTININS IN 8,690 MALE AND FEMALE BLOOD DONORS

\begin{tabular}{ll|c|c|c|c}
\hline \multicolumn{1}{c|}{ Sex } & $\begin{array}{c}\text { No. } \\
\text { Examined }\end{array}$ & $\begin{array}{c}\text { No. } \\
\text { Positive }\end{array}$ & $\begin{array}{c}\text { Per cent. } \\
\text { Positive } \\
1 / 10 \text { or } \\
\text { Over }\end{array}$ & $\begin{array}{c}\text { Male : Female } \\
\text { Ratio of } \\
\text { Positives }\end{array}$ \\
\hline Male & $\cdots$ & 4,345 & 58 & $\begin{array}{c}1 \cdot 33 \\
0.87\end{array}$ & \} $1 \cdot 5: 1$ \\
Female & $\cdots$ & 4,345 & 38 & $1 \cdot 1$ & \} \\
\hline Total & $\cdots$ & 8,690 & 96 & $1 \cdot 1$ \\
\hline
\end{tabular}


lack of information about first trimester abortions, $B r$. abortus does not play much part in early abortion in women.

BLood Donor SERA

Of 8,690 sera examined from blood donors, 96 ( $1 \cdot 1$ per cent.) had titres at $1 / 10$ or over and 36 $(0.41$ per cent.) had titres at $1 / 20$ or over. The proportion of positives in males and females is shown in Table III and the age and sex distribution of positives in Table IV.

TABLE IV

AGE AND SEX DISTRIBUTION OF 96 POSITIVE CASES AMONG BLOOD DONORS

\begin{tabular}{|c|c|c|c|c|c|c|}
\hline \multirow{2}{*}{ Sex } & \multicolumn{5}{|c|}{ Age Group (yrs) } & \multirow{2}{*}{ Total } \\
\hline & $20-29$ & $30-39$ & $40-49$ & $50-59$ & $\begin{array}{c}\text { Not } \\
\text { Known }\end{array}$ & \\
\hline $\begin{array}{l}\text { Male } \\
\text { Female } . .\end{array}$ & $\begin{array}{l}26 \\
10\end{array}$ & $\begin{array}{l}15 \\
12\end{array}$ & $\begin{array}{r}6 \\
11\end{array}$ & $\begin{array}{l}9 \\
5\end{array}$ & $\begin{array}{l}2 \\
0\end{array}$ & $\begin{array}{l}58 \\
38\end{array}$ \\
\hline Total .. & 36 & 27 & 17 & 14 & 2 & 96 \\
\hline
\end{tabular}

The range of titres and the occupational distribution of the positive cases are shown in Table V. The highest titre in the series, $1 / 160$, occurred in a farmer. Of the 96 persons with positive titres, nine (all males) were engaged in farming or allied occupations, 67 were in other kinds of occupation, and in twenty the occupation was unknown. There were 33 persons classifiable as of rural habitation, 33 lived in small towns, and 30 were city dwellers.

TABLE V

RANGE OF BR. ABORTUS AGGLUTINATION TITRES (WHO/FAO ANTIGEN) IN 96 POSITIVE CASES AMONG BLOOD DONORS, BY OCCUPATION

\begin{tabular}{c|c|c|c|c|c|c}
\hline $\begin{array}{c}\text { Positive } \\
\text { Titre }\end{array}$ & \multicolumn{2}{|c|}{ Number of Samples } & \multicolumn{3}{|c|}{ Occupation } \\
\hline $1 / 10$ & 40 & $\begin{array}{c}\text { Fe- } \\
\text { male }\end{array}$ & Total & $\begin{array}{l}\text { Farm, Dairy, etc. } \\
\text { Fale }\end{array}$ & Other & $\begin{array}{c}\text { Un- } \\
\text { known }\end{array}$ \\
\hline $1 / 20$ & 13 & 14 & 27 & $\begin{array}{l}3 \text { farming, } \\
\text { 3 students of } \\
\text { agriculture }\end{array}$ & 40 & 14 \\
\hline $1 / 40$ & 4 & 4 & 8 & $\begin{array}{l}1 \text { laboratory } \\
\text { worker in dairy } \\
\text { student of } \\
\text { agriculture }\end{array}$ & 4 & 2 \\
\hline $1 / 160$ & 1 & 0 & 1 & 1 farmer & 0 & 0 \\
\hline Total & 58 & 38 & 96 & 9 & 67 & 20 \\
\hline
\end{tabular}

The titres recorded from transfusion sera were mostly low, only 0.41 per cent. having titres at or above $1 / 20$. Unfortunately no direct comparability factor is yet available to allow conversion to the
PHLS antigen scale, and the readings might have been higher if the more sensitive PHLS antigen had been used.

The excess of positives in males (ratio $1 \cdot 5: 1$ ) is similar to the sex-ratio in cases of clinical brucellosis, but in the present series the excess occurred entirely in the group with titres of less than $1 / 20$.

The number of persons occupationally connected with farming (nine out of $96,9 \cdot 4$ per cent.) is lower than for clinical brucellosis, which in Great Britain shows 20 to 30 per cent. of occupational cases. The rural : urban ratio of cases was 2 to 1 , corresponding to that in the clinical cases. No significant history or symptoms were recorded in the blood transfusion notes about these donors.

The existence of brucella agglutinins in blood transfusion serum specimens is in itself of some interest, in view of the obvious danger of transmitting the infection by transfusion. Wood (1955) has already recorded such an instance in England; a donor developed brucellosis after blood had been taken, a titre of $1 / 1280$ being recorded; the recipient became unwell 13 weeks after the transfusion, the titre of brucella agglutinins rising to $1 / 2550$. This patient had red cell aplasia and damage to the reticule-endothelial system, and might have been less able to deal with even a few transfused organisms.

In the U.S.A., Spink and Anderson (1950) found that $302(18 \cdot 56$ per cent. of 1,627 transfusion blood samples had agglutinins to $\mathrm{Br}$. abortus, but only 1.66 per cent. of them at $1 / 160$ or above. Viability of the three species of Brucella in transfusion blood was stated to be up to 6 months at $4^{\circ} \mathrm{C}$., yet no case of transmission had been recorded from blood transfusions performed at the University of Minnesota. The chance of infection from the small number of organisms transmitted in this way was considered particularly remote for $\mathrm{Br}$. abortus but conceivable for the more virulent $\mathrm{Br}$. melitensis. Definite transmission by this route has been recorded in Mexico, confirmed by blood culture (Alvarez and Brito, 1944).

COMPARISON OF Br. abortus Agglutinins WITH INCIDENCE IN OTHER SURVeYs (Table VI, opposite)

The percentages of positive agglutination to $\mathrm{Br}$. abortus at over 1/80 found in the present series of pregnant women and of blood donors appear to be much lower than that found in earlier surveys, but differences in the antigen and in the population sampled make conclusions about trends hazardous.

There have been considerable changes in the exposure of the general population to raw milk and thus to possible infection with Br. abortus-in 1930 less than 50 per cent. of milk was heat-treated 
TABLE VI

COMPARISON WITH OTHER SURVEYS

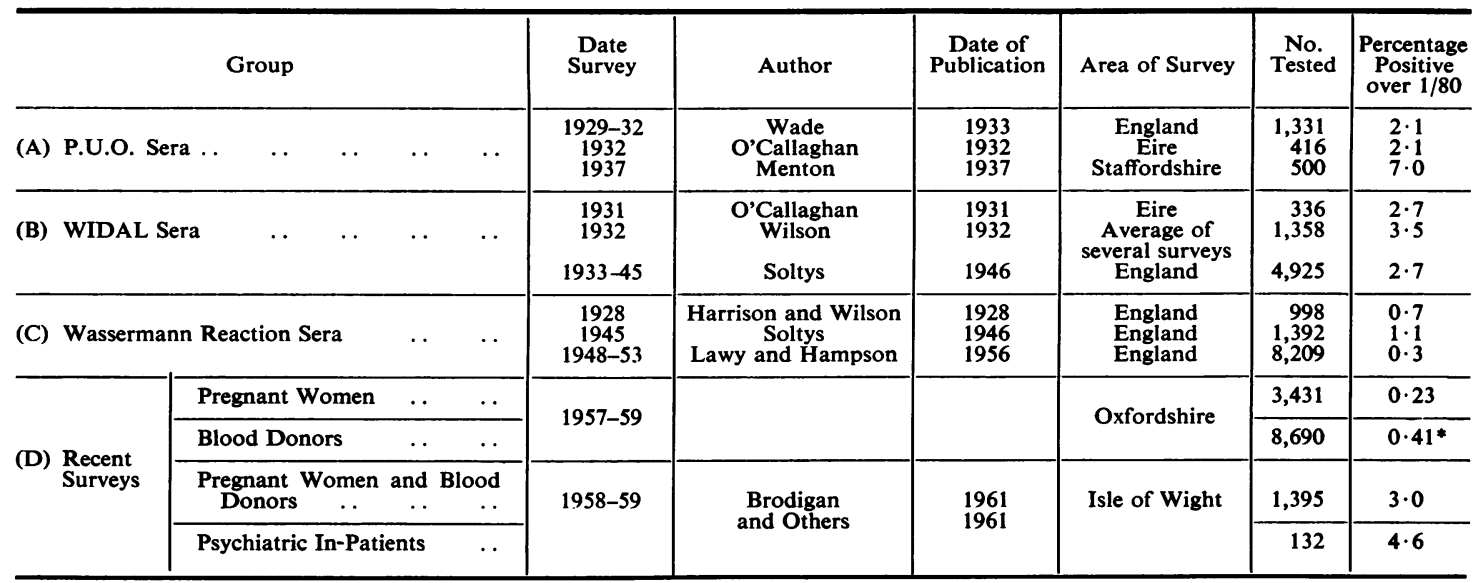

* WHO/FAO antigen over 1/20.

whereas in 1962 this proportion was nearer 95 per cent.--and lower levels of positive agglutinins would therefore be expected. Evidence is available that brucella antibodies persist for a long time, certainly for years; Dalrymple-Champneys (1929) quoted Eyre as stating at least 10 years, and one of us (A.M.) has noted the persistence of agglutinins to $B r$. abortus in a laboratory technician for 8 years. There is, however, no way of knowing whether titres from say $1 / 10$ to $1 / 80$ or even higher represent recently acquired antibodies or merely the persistence of past infection.

In a recent survey in the Isle of Wight, Brodigan, McDiarmid, Mann, and Skone (1961), using comparable PHLS antigen, found that 4.6 per cent. of 132 psychiatric hospital in-patients had titres of $1 / 80$ or more, and that 3 per cent. of 1,393 blood donors and pregnant women had titres of $1 / 80$ or more. These titres are much higher than the Oxford area figures $(0.23$ per cent. over $1 / 80$, and 0.41 per cent. over 1/20 WHO/FAO), and resemble (with the limitations cited) those found in England some 30 years ago. They may reflect exposure to infected milk up to a more recent date in the Isle of Wight, where in $1959 / 6077.3$ per cent. of milk was pasteurized, as against about 95 per cent. in the Oxford area.

\section{Br. abortus Agglutination Tests}

Coombs, Mourant, and Race (1945a, b) described the detection of incomplete or blocking antibodies to Brucella organisms. Wilson and Merrifield (1951) found that the test revealed a further 56.6 per cent. of cases compared with the conventional agglutination. Schrire (1962), reviewing serologic surveys for brucella agglutinins in South Africa, cited the studies of Coetzee (1956) showing $61 \cdot 2$ per cent. with Coombs technique against $19 \cdot 4$ per cent. using the ordinary test. Use of a blocking antibody test in our surveys might have revealed more cases with agglutinins and a further group of pregnant women would then have become available for observation in regard to abortion and course of pregnancy.

The WHO Expert Committee (1958) thought that more work should be carried out to evaluate the Coombs test. Elberg (1958) stated that many of the apparent disadvantages of the tube test could be removed by correct technique and standardized antigens, and he listed procedures to be followed to obviate prozone and incomplete antibody problems.

We have referred to the variation in antigens used in England and Wales (as between PHLS and WHO/FAO), and other instances are known in which test material is incubated at $37^{\circ} \mathrm{C}$. and not at $52^{\circ} \mathrm{C}$., though it is not certain that the temperature used is critical. It is not unlikely that there are variations in the techniques used to detect incomplete antibodies and to obviate prozone difficulties. Since surveys of the incidence of sub-clinical or latent infection, and 95 per cent. of clinical diagnoses of brucellosis, are made on the basis of agglutination tests, the materials and technique of the test should receive attention with a view to standardization. Until such standardization is achieved, we suggest that comparability of survey results might be obtained if samples of serum were tested in parallel with both WHO/FAO antigen and the PHLS antigen. 


\section{SUMMARY}

We have analysed the results of Br. abortus surveys of 3,431 sera from pregnant women and 8,690 sera from blood donors in the Oxford area between 1957 and 1959. Public Health Laboratory Service (PHLS) antigen was used to test the pregnancy sera, and WHO/FAO antigen for the blood donor sera. 1.02 per cent. of pregnancy sera contained agglutinins to $B r$. abortus at titres of $1 / 25$ or over. $1 \cdot 33$ per cent. of male and 0.87 per cent. of female blood transfusion sera contained agglutinins at titres of $1 / 10$ or over. 0.23 per cent. of pregnancy sera gave a titre of $1 / 100$ or over. 0.41 per cent. of transfusion sera had titres of $1 / 20$ or over.

The presence of $\mathrm{Br}$. abortus agglutinins, as detected by the simple tube test, does not appear to be associated with human abortion, but the problem should be studied in a series using a blocking antibody test.

In five out of 35 pregnant women with $\mathrm{Br}$. abortus agglutinins, the organism could be isolated from the milk supply. Routine examination of sera from pregnant women for $\mathrm{Br}$. abortus agglutinins may frequently reveal infected herds if the positive cases are followed up.

Accurate comparison with the results of earlier surveys is not possible, because of differences in the antigens used and in the samples surveyed, but the current series appear to show much lower $B r$. abortus agglutinin titres than earlier surveys.

Our PHLS antigen study on pregnant women's sera had 0.23 per cent. positives at $1 / 100$ or over, compared with 3 and 5 per cent. at $1 / 80$ and over in two recent surveys in the Isle of Wight. Milk pasteurization in the Oxford area was about 95 per cent., however, and in the Isle of Wight 77 per cent.; the differing levels of antibody in these populations can probably be attributed to differences in the duration of exposure to raw infected milk.

The authors are indebted to Sir Graham Wilson for helpful criticism of this paper.

\section{REFERENCES}

Alvarez, M. A., and Brito, A. M. (1944). Cited by Dalrymple-Champneys (1960).

Bothwell, P. W. (1960a). Med. Offr, 103, 85. (1960b). Vet. Rec., 72, 425. (1960c). Ibid., 72, 933.

- (1961). Publ. Hlth (Lond.), 75, 274.

Brodigan, M., McDiarmid, A., Mann, P. G., and Skone, J. F. (1961). Brit. med. J., 2, 1393.

Coetzee, J. N. (1956). S. Afr. J. Lab. clin. Med., 2, 259.

Coombs, R. R. A., Mourant, A. E., and Race, R. R. (1945a). Lancet, $2,15$.

- - - (1945b). Brit. J. exp. Path. 26, 255.

Dalrymple-Champneys, W. (1929). "Undulant Fever", Ministry of Health, Special Reports on Medical Subjects, No. 56.

- (1950). Lancet, 1, 429.

(1960). "Brucella Infection and Undulant Fever in Man". Oxford University Press, London.

Elberg, S. S. (1958). In "Bacterial and Mycotic Infections of Man", ed. R. J. Dubos, 3rd ed., chap. 19. Pitman, London.

Harrison, H., and Wilson, G. S. (1928). Lancet, 2, 1338.

Huddleson, I. F. (1943). "Brucellosis in Man and Animals", 2nd ed. Commonwealth Fund, New York.

Lawy, H., and Hampson, F. (1956). Monthly Bull. Minist. Hlth Lab. Serv., 15, 247.

McDiarmid, A. (1960a). Vet. Rec., 72, 423. (1960b). Ibid., 72, 917.

- (1961). Publ. Hlth (Lond.), 75, 268.

Menton, J. (1937). Brit. med. J., 2, 1273.

O'Callaghan, W. P. (1931). Irish J. med. Sci., 6th ser., No. 71, p. 663 . (1932). J. State Med., 40, 659.

Schrire, L. (1962). S. Afr. med. J., 36, 342.

Soltys, M. A. (1946). J. Path. Bact., 58, 281.

Spink, W. W., and Anderson, D. (1950). J. Lab. clin. Med., 35, 440.

Wade, E. (1933). Lancet., 1, 1342.

Williamson, A. R. H. (1944). Brit. med. J., 1, 752 (Letter).

Wilson, M. M., and Merrifield, E. V. O. (1951). Lancet, 2,913 .

Wilson, G. S. (1932). Vet. Rec., 12, 1240. (1961). Personal communication.

Wood, E. E. (1955). Brit. med. J., 1, 27.

World Health Organization (1958). "Report on Brucellosis", W.H.O. tech. Rep. Ser., No. 148. 